\title{
STUDI FLORISTIK DI KAWASAN PLASMA NUTFAH UNTUK MENDUKUNG PENETAPAN PLOT KONSERVASI GENETIK TENGKAWANG (Shorea spp) DI KALIMANTAN BARAT
}

Floristic Study at Germplasm Area for Supporting Shorea spp Genetic Conservation Area in West Kalimantan

\author{
Jayusman \\ Balai Besar Penelitian Bioteknologi dan Pemuliaan Tanaman Hutan \\ Jl. Palagan Tentara Pelajar Km. 15, Purwobinangun, Pakem, Sleman, Yogyakarta 55582 \\ Telp. (0274) 895954, 896080, Fax. (0274) 896080
}

Naskah masuk : 25 April 2011 - Naskah diterima : 27 Oktober 2011

\begin{abstract}
A research was done at natural tropical forest in forest concession of PT. Suka Jaya Makmur (SJM), Ketapang, West Kalimantan. The objective of the study is germplasm area in natural forest. The aims of this floristic study were to investigate the potensial and distribution of tengkawang tree species. Tengkawang kernel is one of the famous Non-wood Forest Product (NWFP), it is resources of an importance vegetable fat. The inventory was conducted using line plot method in each area of 26 Hectares. 130 sample plots were made up systematically within 13 line plot. The sample plot had a square shape with nested sampling area, measured $20 \mathrm{~m} \times 20 \mathrm{~m}$ for tree stage, $10 \mathrm{~m} \times 10 \mathrm{~m}$ for pole stage, $5 m \times 5 m$ for sapling stage and $2 m \times 2 m$ for seedling stage. The result reveal that the germplasm consisted of 75 species were dominated by industrial wood species. The germpalsm area was dominated by Shorea leprosula with importance value (31.01\%), Eugenia cymosa (26.32\%), Litsea firma (18.11\%) and Shorea laevis (16.02\%) respectively. Some tengkawang trees were found in the study area with important value were varied were Shorea pinnanga (9.43\%), Shorea macrophylla (4.11\%), Shorea macistopterix (0.63\%) respectively but the famous of tengkawang tree (Shorea stenoptera) was not found in the study area. Therefore, block 35 \& 36 PT SJM germplasm area unrepresentative for tengkawang genetic conservation plot.
\end{abstract}

\section{Key Words : Germplasm, Industrial Wood Species, species important value and tengkawang tree}

\begin{abstract}
ABSTRAK
Penelitian dilaksanakan di hutan alam yang dikelola PT. Suka Jaya Makmur (SJM) di Ketapang, Kalimantan Barat. Lokasi penelitian adalah areal plasma nutfah yang telah ditetapkan. Studi floristik ditujukan untuk identifikasi potensi dan distribusi jenis-jenis penghasil tengkawang. Biji tengkawang adalah salah satu hasil hutan bukan kayu yang terkenal dan dimanfaatkan sebagai sumberdaya lemak
\end{abstract}


nabati yang penting. Inventarisasi dan studi floristik menggunakan metoda jalur yang tersebar pada areal seluas $26 \mathrm{Ha}$. Sebanyak 130 plot disusun secara sistematis di dalam 13 jalur. Plot pengukuran berbentuk persegi empat yang terletak di dalam jalur pengamatan, plot dengan ukuran $20 \mathrm{~m}$ x $20 \mathrm{~m}$ untuk pengamatan pohon, $10 \mathrm{~m} \times 10 \mathrm{~m}$ untuk pengamatan tiang, plot $5 \mathrm{~m} \times 5 \mathrm{~m}$ untuk pengamatan pancang dan $2 \mathrm{~m} \times 2 \mathrm{~m}$ untuk pengamatan semai. Hasil analisis vegetasi di areal plasma nutfah menunjukkan bahwa terdapat 75 jenis yang didominasi jenis kayu industri. Shorea leprosula menduduki nilai penting (NP) terbesar (31,01\%) diikuti Eugenia cymosa (26,32\%), Litsea firma $(18,11 \%)$ dan Shorea laevis (16,02\%). Beberapa pohon tengkawang ditemukan di dalam areal plasma nutfah dengan nilai penting (NP) bervariasi yaitu Shorea pinnanga (9,43\%), Shorea macrophylla $(4,11 \%)$ dan Shorea macistopterix (0,63\%), namun jenis tengkawang tungkul (Shorea stenoptera) tidak ditemukan di dalam areal penelitian. Untuk itu area plasma nutfah pada petak 35 dan 35 PT. SJM kurang sesuai untuk ditetapkan sebagai plot konservasi genetik penghasil tengkawang.

\section{Kata Kunci : Plasma nutfah, pohon tengkawang, jenis kayu industri dan nilai penting jenis}

\section{PENDAHULUAN}

Indonesia memiliki sumberdaya hutan dengan keanekaragaman hayati (megabiodiversity) dan endemisme (keunikan) yang sangat tinggi. Hutan Indonesia juga diketahui memiliki keanekaragaman jenis pohon palem (Aracaceae) tertinggi di dunia, lebih dari 400 spesies (70\%) pohon meranti (Dipterocarpaceae) terbesar di dunia sebagai jenis kayu tropika primadona. Dipterocarpaceae merupakan salah satu suku besar dengan jumlah jenis di seluruh dunia mencapai 506 jenis, tergolong dalam 14 marga yang sebagian besar (76\%) jenis tumbuh di kawasan Malesia, terutama di Indonesia. Secara geografis, persebaran jenis dipterocarp tidak merata di wilayah Indonesia, berbeda dengan jenis dari suku lain misalnya Myrtaceae, Euphorbiaceae, Lauracaeae, Moraceae, dan Annoceae yang umumnya mempunyai persebaran luas atau pantropis (Bawa,1998).
Kelompok dipterocarpaceae menguasai lebih dari $80 \%$ potensi dan lapisan tajuk paling atas dari struktur tegakan pohon. Dari 13 genera yang tumbuh alami di Asia, 9 genera tersebar di Indonesia yaitu Anisoptera spp, Shorea spp, Cotylelobium spp, Dryobalanops spp, Hopea spp, Parashorea, Upuna spp, Vatica spp dan Dipterocarpus spp. Kelompok dipterocarpaceae ini telah banyak menyumbang sangat besar dalam perekonomian negara terutama dari jenis Shorea spp (Krisnapillay dan Tomsett, 1998).

Kerusakan hutan tropis Indonesia akan berakibat serius baik ekologis, ekonomis dan sosial. Hutan Dipterocarpaceae telah mengalami degradasi yang sangat cepat, hal ini disebabkan proses pembalakan yang terjadi secara terus-menerus dengan skala besar (Purwaningsih, 2004).

Mengacu pada Rekomendasi Litbang Dipterocarpaceae di Indonesia butir 2, tentang penyelamatan keragaman genetik untuk kepentingan pemuliaan; butir 3, tentang 
konservasi: butir 5 dan 6 , tentang penelitian aspek ekonomi, sosial dan budaya baik kayu maupun penghasil bukan kayu. Maka konservasi in-situ jenis-jenis tanaman prioritas, potensial dan langka difokuskan pada jenis-jenis Shorea peng- hasil tengkawang sebagai kelompok jenis target. Sebanyak 13 jenis Shorea penghasil tengkawang, 11 diantarannya ada di Kalimantan bagian barat yaitu Shorea macrantha, S. macrophylla, S. mecistopteryx, S. palembanica, S. pinanga, S. splendida, S. stenoptera, S. balanocarpoides, S. faguetiana, S. gibbosa dan $S$. seminis.

Anggota dari famili dipterocarpaceae mempunyai nilai ekonomi yang tinggi baik yang berupa kayu, buah maupun hasil metabolit sekundernya. Anggota famili dipterocarpaceae yang potensial menghasilkan buah tengkawang adalah genus Shorea spp. Biji tengkawang (Borneo illipe nut) merupakan salah satu hasil hutan bukan kayu penting terutama untuk bahan baku lemak nabati. Biasanya mentega tengkawang ini digunakan untuk campuran coklat dan kosmetika. Dipterocarp yang menghasilkan biji tengkawang adalah misalnya Shorea pinanga, Shorea stenoptera, Shorea macroptera, dan Shorea mecistopterix (Tantra, 1979). Masyarakat di sekitar hutan Kalimantan membuat minyak goreng dari buah tengkawang (Anderson, 1975). Umumnya biji tengkawang dipungut dari pohon tengkawang yang tumbuh di hutan alam, sehingga perlindungan terhadap eksistensi pohon penghasil tengkawang sangat penting dilakukan. Tengkawang kaya akan lemak dan sudah dikenal oleh masyarakat Kalimantan secara turun temurun sebagai campuran makanan, bahan baku dari industri coklat, krim, kosmetik dan obat- obatan (Sumadiwangsa, 2001). Jenis-jenis yang memegang peran kunci dalam suatu ekosistem dan memiliki prospek ekonomi yang tinggi akan diprioritaskan untuk dikonservasi (Finkeldey, 2005). Pemanfaatan jenis prioritas di kawasan plasma nutfah memiliki peran strategis dalam mendukung pembangunan hutan industri dimasa mendatang (Thomson, 1993).

Tujuan penelitian adalah (a) mendapatkan data dan informasi floristik terutama jenis-jenis Shorea penghasil tengkawang, Indeks Nilai Penting (INP) dan indeks kesamaan komunitas dan (b) mengetahui potensi jenis-jenis Shorea penghasil tengkawang sebagai dasar menetapkan lokasi plot konservasi sumberdaya genetik jenisjenis tengkawang.

\section{BAHAN DAN METODE PENELITIAN}

\section{A. Lokasi Kegiatan}

Areal Plasma Nutfah berada di petak 35 dan 36, areal konsesi HPH PT. Suka Jaya Makmur (SJM), Kabupaten Ketapang, Propinsi Kalimantan Barat. Ketinggian tempat 450-500 m dpl.

\section{Jenis Tanah dan Geologi}

Lokasi didominasi oleh jenis tanah Podsolik Merah Kuning (PMK) dengan bahan induk batuan beku dan endapan dan metamorf serta fisiografi intrusi dengan bentuk wilayah berbukit. Tanah bertekstur liat berpasir, solum dalam ( $>90$ $\mathrm{cm}$ ), draenase sedang hingga baik dan Kapasitas Tukar Kation (KTK) termasuk rendah. Geologi didominasi oleh formasi kompleks granit mendahan sebesar 44,45\% (Kerangka Acuan Dokumen Amdal PT. Suka Jaya Makmur, 1992). 


\section{Topografi}

Topografi areal Plasma Nutfah curam-sangat curam $(>40 \%)$ sehingga sangat berat dalam kegiatan inventarisasi. Kondisi ini memang sesuai dengan kriteria areal Plasma Nutfah sehingga tidak dapat dijamah oleh manusia untuk dapat mempertahankan plasma nutfah baik flora maupun faunanya.

\section{Tipe Iklim}

Menurut klasifikasi iklim Schmidt dan Ferguson, lokasi bertipe iklim A (sangat basah) dengan nilai $\mathrm{Q}=4,8-9,7 \%$, perbandingan bulan kering (curah hujan $<60 \mathrm{~mm}$ ) dengan bulan basah (curah hujan $>100 \mathrm{~mm}$ ) adalah 6:6. Rata-rata curah hujan bulanan berkisar antara 179-369 mm, rata-rata curah hujan tahunan $3.140 \mathrm{~mm}$. Curah hujan rata-rata tertinggi pada bulan Nopember (369 mm) dan terendah bulan Agustus (179 mm). Jumlah hari hujan rata-rata bulanan antara 15-26 hari. Setahun jumlah hari hujan mencapai 241 hari. Suhu udara makro rata-rata bulanan antara $26,3^{\circ} \mathrm{C}-27,5^{\circ} \mathrm{C}$, rata-rata tahunan mencapai $26,9^{\circ} \mathrm{C}$. Kelembaban udara makro rata-rata bulanan antara $82-87 \%$, rata-rata tahunan $85 \%$ (PT. SJM, 1992).

\section{B. Metode Penelitian}

Metode penelitian yang digunakan adalah inventarisasi potensi, komposisi dan distribusi jenis-jenis Shorea penghasil tengkawang yang dilakukan dengan menggunakan teknik systematic line plot melalui pembuatan jalur pengamatan lebar $20 \mathrm{~m}$ dan panjang $1.000 \mathrm{~m}$, jumlah jalur sebanyak 13. Sebanyak 130 plot disusun secara sistematis di dalam 13 jalur. Plot pengukuran berbentuk persegi empat yang terletak didalam jalur pengamatan, plot dengan ukuran $20 \mathrm{~m}$ x $20 \mathrm{~m}$ untuk pengamatan pohon, plot $10 \mathrm{~m} \times 10 \mathrm{~m}$ untuk pengamatan tiang, $5 \mathrm{~m} \times 5$ $\mathrm{m}$ untuk pengamatan pancang dan $2 \mathrm{~m} \times 2 \mathrm{~m}$ untuk pengamatan semai.

\section{Alat dan Bahan}

Alat dan bahan yang diperlukan untuk kegiatan inventarisasi dan koleksi herbarium antara lain peta kerja HPH, pengukur sudut blok (kompas), pengukur azimut (Global Position System atau GPS), pengukur ketinggian tempat dari permukaan laut (altimeter), pengukur diameter pohon (phiband), pengukur ketinggian pohon (hagameter), tali plastik, clipboard, pengukur kelerengan lahan (clinometer), gunting, silicagel, plastik, spirtus, kertas koran, cat, kuas, golok, pengukur suhu dan kelembaban (thermohigrometer), tallysheet, milimeter blok, alat tulis dan kamera.

\section{Analisis Data}

Analisis floristik dilakukan berdasarkan rumus Odum (1971) dan cara Soerianegara dan Hendrawan (1978) dengan menghitung Kerapatan (K); Kerapatan Relatif(KR); Dominasi Relatif (DR); Frekuensi (F); Frekuensi Relatif(FR) dan Nilai Penting (NP). Nilai NP mencerminkan peran dan pengaruh suatu jenis terhadap komunitasnya, semakin tinggi nilai NP suatu jenis maka semakin besar peran dan pengaruhnya terhadap suatu komunitas vegetasi hutan. Nilai NP yang tinggi dapat dilihat dari banyaknya jumlah individu suatu jenis terdistribusi merata di seluruh komunitasnya dengan ukuran diameter batang dan/atau tajuknya. Jenis yang bernilai NP tinggi merupakan jenis dominan (stratum A). Untuk menduga kesamaan kondisi lingkungan antar tingkat digunakan indeks kesamaan 
komunitas menurut Jaccard (Mueller Combois dan Illenberg, 1974 dalam Sutisna, 1981).

\section{HASIL DAN PEMBAHASAN}

Berdasarkan hasil analisis vegetasi tingkat semai sampai dengan tingkat pohon ditemukan 75 jenis yang didominasi oleh jenis-jenis kayu industri, di samping itu juga ditemukan jenis tumbuhan obat, buah-buahan dan tanaman hias. Jumlah jenis yang ditemukan lebih tinggi dibandingkan pengamatan di Sintang-Kalimantan Barat yang menemukan 55 jenis (Heriyanto dan Subiandono, 2003). Hasil perhitungan terhadap nilai kerapatan Relatif (KR), Frekuensi Relatif (FR), Dominasi Relatif (DR) dan Nilai Penting (NP) untuk tiap jenis tumbuhan pada semua tingkat dilaporkan di bawah ini.

\section{Kerapatan Jenis}

Berdasarkan jenis target difokuskan pada penghasil tengkawang, maka dilakukan analisis seberapa besar kedudukan jenis-jenis tersebut dibandingkan jenis dominan lainnya berdasarkan nilai KR dan hasilnya tertuang pada Tabel 1.

Tabel 1.Kerapatan Relatif (KR) beberapa jenis yang berperanan pada masing-masing tingkat pohon, tiang, pancang dan semai

\begin{tabular}{|c|c|c|c|}
\hline \multicolumn{2}{|c|}{ Tingkat Pohon } & \multicolumn{2}{|c|}{ Tingkat Tiang } \\
\hline Jenis & $\begin{array}{c}\text { Kerapatan Relatif } \\
(\%)\end{array}$ & Jenis & $\begin{array}{c}\text { Kerapatan Relatif } \\
(\%)\end{array}$ \\
\hline Shorea leprosula & 11,96 & Eugenia cymosa & 11,79 \\
\hline Eugenia cymosa & 9,88 & Myristica spp. Gronov & 10,00 \\
\hline Litsea firma (Blume) & 6,69 & Shorea leprosula & 9,10 \\
\hline Shorea laevis & 2,09 & Litsea firma (Blume) & 8,21 \\
\hline Shorea macroptera & 4,72 & Palaquium obovatum & 6,42 \\
\hline Dryobalanop oblifolia & 3,62 & Polyalthia rumphii & 4,33 \\
\hline Dacryodes spp & 2,85 & Shorea macroptera & 4,18 \\
\hline Polyalthia rumphii & 2,63 & Polyalthia hypoleuca & 3,73 \\
\hline Nephelium mutabile & 2,52 & Dacryodes spp & 3,28 \\
\hline Palaquium obovatum & 2,41 & Shorea pinanga & 2,99 \\
\hline Shorea pinanga & 2,92 & Shorea macropylla & 0,45 \\
\hline Shorea macistopterix & 0,27 & Shorea macistopterix & 0,05 \\
\hline Shorea macropylla & 1,46 & & \\
\hline \multicolumn{2}{|c|}{ Tingkat Pancang } & \multicolumn{2}{|c|}{ Tingkat Semai } \\
\hline Jenis & $\begin{array}{c}\text { Kerapatan Relatif } \\
(\%)\end{array}$ & Jenis & $\begin{array}{c}\text { Kerapatan Relatif } \\
(\%)\end{array}$ \\
\hline Shorea laevis & 14,72 & Shorea laevis & 22,45 \\
\hline Shorea leprosula & 14,41 & Shorea macroptera & 7,06 \\
\hline Knema mandarahan & 8,91 & Shorea leprosula & 6,02 \\
\hline Eugenia cymosa & 7,72 & Litsea firma (Blume) & 5,38 \\
\hline Litsea firma (Blume) & 7,67 & Knema mandarahan & 5,03 \\
\hline Palaquium obovatum & 5,78 & Eugenia cymosa & 4,40 \\
\hline Shorea macroptera & 4,43 & Palaquium obovatum & 4,22 \\
\hline Shorea pinanga & 3,62 & Shorea pinanga & 3,93 \\
\hline Glutta wallichii & 2,75 & Shorea johorensis & 3,76 \\
\hline Polyalthia hypoleuca & 2,43 & Dacryodes spp & 3,30 \\
\hline Shorea macropylla & 1,140 & Shorea macropylla & 2,08 \\
\hline Shorea macistopterix & 0,05 & Shorea macistopterix & 1,45 \\
\hline
\end{tabular}


Berdasarkan nilai KR pada Tabel 1 tidak ada jenis yang memegang peranan kuat pada semua tingkatan seperti jenis bangkirai (Shorea laevis) yang hanya menguasai tingkat semai dan pancang, sedangkan pada tingkat tiang digantikan jenis Ubar (Eugenia cymosa) dan tingkat pohon diduduki oleh jenis Meranti merah (Shorea leprosula). Kondisi tersebut setidaknya menciptakan peluang seluruh jenis bersaing dan tersebar merata untuk memperoleh kesempatan tumbuh dan hidup terus tidak terkecuali oleh tiga jenis Shorea penghasil tengkawang (Shorea pinanga, Shorea macropylla, Shorea macistopterix) meskipun memiliki nilai KR yang relatif sangat kecil.

\section{Penyebaran Jenis}

Tingkat penyebaran suatu jenis terhadap jenis lainnya dapat diprediksi dari nilai Frekuensi Relatif(FR). Nilai FR yang tinggi mencerminkan tingkat dominasi jenis di lokasi tempat tumbuhnya, hal ini ditunjukkan oleh jenis bengkirai (Shorea laevis) pada tingkat semai,

Tabel 2.Frekuensi Relatif beberapa jenis yang berperanan pada masing-masing tingkat pohon,tiang, pancang dan semai

\begin{tabular}{|lclc|}
\hline \multicolumn{2}{|c|}{ Tingkat Pohon } & \multicolumn{2}{c|}{ Tingkat Tiang } \\
\hline \multicolumn{1}{|c}{ Jenis } & Kerapatan Relatif & Kerapatan Relatif \\
& $(\boldsymbol{\%})$ & Eugenia cymosa \\
\hline Shorea leprosula & $9,28^{*}$ & Myristica spp. Gronov & $10.20^{*}$ \\
Eugenia cymosa & 9,15 & Shorea leprosula & 8,93 \\
Litsea firma (Blume & 6,50 & Litsea firma (Blume) & 7,83 \\
Shorea macroptera & 4,77 & Palaquium obovatum & 7,83 \\
Dryobalanop oblongifolia & 3,45 & Polyalthia rumphii & 5,83 \\
Dacryodes spp & 3,18 & Polyalthia hypoleuca & 5,10 \\
Polyalthia rumphii & 3,05 & Shorea macroptera & 4,01 \\
Nephelium mutabile & 2,65 & Dacryodes spp & 3,83 \\
Shorea laevis & 2,39 & Shorea pinanga & 3,64 \\
Palaquium obovatum & 2,39 & & 3,10 \\
Shorea pinanga & & Shorea macropylla & 0,18 \\
Shorea macistopterix & 2,92 & Shorea macistopterix & 0,13 \\
Shorea macropylla & 0,27 & & \\
\hline
\end{tabular}

\begin{tabular}{|c|c|c|c|}
\hline \multicolumn{2}{|c|}{ Tingkat Pancang } & \multicolumn{2}{|c|}{ Tingkat Semai } \\
\hline Jenis & $\begin{array}{c}\text { Kerapatan Relatif } \\
(\%)\end{array}$ & Jenis & $\begin{array}{c}\text { Kerapatan Relatif } \\
(\%)\end{array}$ \\
\hline Myristica spp. Gronov & 10,37 & Shorea laevis & $8,79^{*}$ \\
\hline Eugenia cymosa & 8,85 & Litsea firma (Blume) & 8,49 \\
\hline Litsea firma (Blume) & 8,22 & Myristica spp. Gronov & 7,87 \\
\hline Palaquium obovatum & 7,59 & Eugenia cymosa & 6,94 \\
\hline Shorea leprosula & 6,57 & Shorea leprosula & 6,33 \\
\hline Shorea laevis & 5,06 & Palaquium obovatum & 5,40 \\
\hline Shorea macroptera & 4,93 & Shorea macroptera & 4,94 \\
\hline Glutta wallichii & 4,30 & Shorea pinanga & 3,86 \\
\hline Polyalthia hypoleuca & 3,29 & Dacryodes spp & 3,39 \\
\hline Polyalthia rumphii & 3,03 & Polyalthia hypoleuca & 2,93 \\
\hline Shorea pinanga & 2,91 & Shorea macropylla & 1,54 \\
\hline Shorea macistopterix & 0,13 & Shorea macistopterix & 0,46 \\
\hline Shorea macropylla & 1,26 & & \\
\hline
\end{tabular}


jenis kumpang (Myristica spp. Gronov) pada tingkat pancang, jenis Ubar (Eugenia cymosa) pada tingkat tiang dan jenis Meranti merah (Shorea leprosula) pada tingat pohon. Nilai FR yang dimiliki masing-masing jenis dominan tersebut juga menunjukkan adanya tingkat persaingan sesama jenis tersebut.

Pergantian jenis yang mendominasi pada masing-masing tingkat menunjukkan bahwa pertumbuhan pohon pada setiap tingkat membutuhkan persyaratan tempat tumbuh yang berbeda, pada suatu tingkat tertentu suatu jenis apabila tumbuh dalam kondisi yang tidak berubah maka akan mengalami hambatan, namun jenis lain yang sesuai dengan kondisi tempat tumbuh tersebut akan muncul sebagai pemenang dalam kompetisi memperebutkan ruang tumbuh. Hal ini terlihat pada tingkat semai jenis bangkirai (Shorea laevis) begitu dominan namun pada tingkat pancang digantikan oleh jenis kumpang (Myristica spp) dan ubar (Eugenia cymosa). Namun ada juga jenis yang tidak muncul pada tingkat tiang tetapi muncul pada tingkat pohon.
Pada kondisi tersebut jenis-jenis penghasil tengkawang yang memiliki nilai FR rendah akan berkompetisi lebih berat untuk mempertahankan kehidupannya.

\section{Dominasi Jenis dan Nilai Penting}

Berdasarkan nilai KR dan FR yang diperoleh, antara nilai KR dan FR adalah sebanding, atau dengan kata lain apabila nilai KR tinggi maka nilai FR juga tinggi, namun bila dibandingkan nilai DR maka nilainya akan beragam seperti jenis medang (Litsea firma) dengan nilai KR6,69, FR-6,50 tetapi nilai DR-4,92, jenis bangkirai (Shorea laevis) dengan nilai KR-2,09, FR-2,39 dan DR-11. Hal ini berkaitan dengan tingkat keragaman diameter pohon jenis-jenis cepat tumbuh yang tentunya mempengaruhi nilai DR, sehingga menyebabkan munculnya keragaman yang mencolok dan hal ini sebaliknya terjadi pada jenis yang pertumbuhannya lambat maka seringkali nilai DR jenis tersebut tidak menunjukkan perbedaan yang nyata. Peranan suatu jenis tidak hanya ditentukan nilai $\mathrm{KR}$ dan FR saja tetapi juga nilai DR. Jenis pohon

Tabel 3. Daftar Nilai Dominasi Relatif (DR) 15 jenis yang berperanan pada tingkat tiang dan pohon

\begin{tabular}{|l|l|c|c|}
\hline No & \multicolumn{1}{|c|}{ Jenis } & Tiang & Pohon \\
\hline 1 & Shorea laevis & - & $11,54^{*}$ \\
2 & Shorea leprosula & $13,29 *$ & 9,77 \\
3 & Eugenia cymosa & 9,33 & 7,29 \\
4 & Dipterocarpus elongatus & - & 5,90 \\
5 & Litsea firma (Blume) & - & 4,92 \\
6 & Shorea macroptera & - & 4,79 \\
7 & Dryobalanop oblongifolia & - & 4,19 \\
8 & Myristica spp. Gronov & 9,11 & - \\
9 & Polyalthia hypoleuca & 7,00 & - \\
10 & Litsea firma (Blume) & 6,85 & - \\
11 & Polyalthia rumphii & 4,54 & - \\
12 & Dipterocarpus elongatus & 4,29 & - \\
13 & Shorea pinanga & 1,81 & 3,44 \\
14 & Shorea macistopterix & - & 0,14 \\
15 & Shorea macropylla & 3,34 & 1,93 \\
\hline
\end{tabular}


dikategorikan dominan apabila jenis tersebut terdapat dalam jumlah banyak, tumbuh tersebar dalam areal dan memiliki diameter batang besar disamping dijumpai namun juga dalam jumlah melimpah.

Berdasarkan Tabel 3 maka jenis-jenis penghasil tengkawang yang terdapat di lokasi pengamatan tidak menunjukkan nilai dominasi yang tinggi dan bahkan jenis Shorea macistopterix pada tingkat tiang tidak ditemukan.

Kesesuaian pertumbuhan suatu jenis pada suatu komunitas sebagai kombinasi pertumbuhan yang beranekaragam sifatnya dapat dilihat dari nilai urutan Nilai Penting (NP). Nilai NP tinggi mengindikasikan jenis bersangkutan memiliki peranan penting di areal hutan.
Pengelompokan jenis pohon dominan berdasarkan nilai penting menggunakan kriteria seperti disajikan pada Tabel 5.

Berdasarkan kriteria pengelompokan tersebut maka 4 jenis yang memiliki kriteria sangat berperan adalah jenis Meranti merah (Shorea leprosula), Ubar (Eugenia spp), Medang (Litsea firma (Blume) Hook f.), dan Bangkirai (Shorea laevis). Hal ini dapat dijadikan dasar bahwa kondisi kawasan hutan tersebut sangat sesuai bagi perkembangan ke-4 jenis tersebut, namun sebaliknya kurang sesuai bagi pertumbuhan 27 jenis yang memiliki nilai $\mathrm{NP}<1$. Selain itu terdapat jenis yang mampu muncul sebagai jenis yang sangat berperan di dalam komunitas pada tingkat semai dan pohon saja. Jumlah jenis maupun nilai penting (NP) seperti disajikan pada Tabel 4 memiliki kesamaan dengan laporan

Tabel 4. Nilai Penting beberapa 12 jenis dengan nilai terbesar

\begin{tabular}{|c|l|c|c|c|c|}
\hline No & \multicolumn{1}{|c|}{$\begin{array}{c}\text { Kerapatan } \\
\text { Relatif } \\
(\mathrm{KR})\end{array}$} & $\begin{array}{c}\text { Frekuensi } \\
\text { Relatif } \\
\text { (FR) }\end{array}$ & $\begin{array}{c}\text { Dominasi } \\
\text { Relatif } \\
\text { (DR) }\end{array}$ & $\begin{array}{c}\text { Nilai } \\
\text { Penting } \\
\text { (NP) }\end{array}$ \\
\hline 1 & Shorea leprosula & 11,96 & 9,28 & 9,767 & 31,01 \\
2 & Eugenia cymosa & 9,88 & 9,15 & 7,290 & 26,32 \\
3 & Litsea firma (Blume) & 6,69 & 6,50 & 4,919 & 18,11 \\
4 & Shorea laevis & 2,09 & 2,39 & 11,544 & 16,02 \\
5 & Shorea macroptera & 4,72 & 4,77 & 4,798 & 14,29 \\
6 & Dryobalanop oblifolia & 3,62 & 3,45 & 4,197 & 11,27 \\
7 & Shorea pinanga & 3,07 & 2,92 & 3,435 & 9,43 \\
8 & Shorea palembanicca & 1,98 & 2,25 & 4,106 & 8,34 \\
9 & Dacryodes spp & 2,85 & 3,18 & 1,592 & 7,63 \\
10 & Polyalthia rumphii & 2,63 & 3,05 & 1,162 & 6,85 \\
11 & Shorea macrophylla & 2,10 & 1,46 & 0,551 & 4,11 \\
12 & Shorea macistopterix & 0,22 & 0,27 & 0,143 & 0,63 \\
\hline
\end{tabular}

Tabel 5. Kriteria pengelompokan jenis berdasarkan nilai penting (NP) pada tingkat pohon

\begin{tabular}{|c|l|c|c|}
\hline No & \multicolumn{1}{|c|}{ Kriteria } & Nilai Penting & Distribusi \\
\hline 1 & Sangat berperan & $>15$ & 4 jenis \\
2 & Cukup berperan & $7,5-15$ & 5 jenis \\
3 & Kurang berperan & $1,0-7,49$ & 18 jenis \\
4 & Langka/tidak berperan & $<1$ & 27 jenis \\
\hline
\end{tabular}


sebelumnya dimana jenis Litsea firma (Blume), Shorea leprosula Miq dan Eugenia spp Lour hampir terdapat di setiap petak dan memiliki peringkat nilai NP tinggi bahkan sebagian besar menduduki peringkat pertama (Sofia dan Riswan, 2008). Hasil berbeda terjadi oleh dominasi suku Dipterocarpaceae yaitu jenis Shorea, Vatica dan Dipterocarpus pada tingkat semai dan pancang serta jenis Callophyllum, Sterculia, Syzygium dan Glutta pada tingkat tiang dan pohon (Hidayat, 2007). Dominasi berbeda oleh Shorea parvifolia dengan Nilai Penting (77,79\%), Melanochyla tomentosa (57,04\%), Palaquium obovatum (17,23\%) dan Shorea macroptera $(15,47 \%)$ (Heriyanto dan Subiandono, 2003).

Jenis Shorea pinanga sebagai salah satu penghasil tengkawang menduduki kriteria 2 atau cukup berperan dalam kawasan hutan tersebut, sedangkan Shorea macrophylla dan Shorea macistopterix berada pada kriteria 3 dan 4 atau kurang berperan bahkan termasuk langka dalam kawasan tersebut. Berdasarkan tipe komposisi jenis pohon seperti diatas, maka kawasan hutan tersebut akan menjadi satu ekosistem ekologi yang akan dipengaruhi oleh sifat-sifat pohon kiteria 1 dan 2. Pengetahuan terhadap sistem ekologi yang berlaku pada suatu kawasan hutan merupakan dasar pertimbangan biologis dalam pengelolaan kawasan hutan pada masa mendatang.

\section{Kesamaan Komposisi Jenis}

Berdasarkan perhitungan terhadap indeks kesamaan komunitas menurut Jaccard maka kesamaan komposisi jenis antar tingkat pertumbuhan menunjukkan kesamaan komposisi semai dengan dengan pohon $24,46 \%$, komposisi semai dengan tiang 29,17\%, komposisi semai dengan pancang $31,54 \%$, komposisi pancang dengan tiang $26,57 \%$, komposisi pancang dengan pohon 22,84\% dan komposisi tiang dengan pohon $27,42 \%$. Komposisi jenis antar tingkat sangat beragam, indeks terbesar adalah $31,54 \%$ yaitu antara tingkat semai dengan pancang dan

Tabel 6. Daftar beberapa jenis yang berperanan penting pada setiap tingkatan

\begin{tabular}{|l|c|c|c|c|c|}
\hline \multicolumn{1}{|c|}{ Jenis } & Semai & Pancang & Tiang & Pohon & Keterangan \\
\hline Shorea laevis & + & + & - & - & Kriteria 2 \\
Shorea leprosula & + & + & + & + & Kriteria 1 \\
Eugenia cymosa & + & + & + & + & Kriteria 1 \\
Litsea firma (Blume & + & + & + & + & Kriteria 1 \\
Palaquium obovatum & + & + & + & - & Kriteria 2 \\
Shorea macroptera & + & - & - & + & Kriteria 2 \\
Myristica spp. Gronov & + & + & + & - & Kriteria 2 \\
Polyalthia rumphii & - & - & + & - & Kriteria 3 \\
Shorea pinanga & - & - & - & - & Kriteria 4 \\
Shorea macistopterix & - & - & - & - & Kriteria 4 \\
Shorea macrophylla & - & - & - & - & Kriteria 4 \\
\hline
\end{tabular}

Keterangan:

1. $(+)$ ada (present) dan ( - ) tidak ada (absent)

2.Persyaratan kriteria :

a. Kriteria 1 adalah jenis yang berperan penting pada semua tingkatan (yaitu tingkat semai, pancang, tiang dan pohon)

b. Kriteria 2 adalah jenis yang berperan penting pada 2-3 tingkatan.

c. Kriteria 3 adalah jenis berperan penting pada 1 tingkatan

d. Kriteria 4 adalah jenis yang tidak berperan penting pada semua tingkatan 
komposisi semai dengan tiang $29,17 \%$. Kondisi tersebut akan menggambarkan kemungkinan jenis yang ada pada tingkat semai akan mampu mencapai tingkat tiang pada periode berikutnya. Namun bila sangat memungkinkan tidak akan mencapai tingkat tiang dan pohon karena banyak jenis fase semai yang tidak berlanjut hingga fase tiang dan pohon. Hal lain adalah kemungkinan jenis yang dominan pada fase pancang tidak berlanjut pada fase tiang atau bahkan tingkat pohon. Jenis-jenis meranti merah (Shorea leprosula), kumpang (Myristica spp. Gronov) dan ubar (Eugenia cymosa) berkesempatan menjadi jenis yang sangat berperan di kawasan plasma nutfah tersebut.

\section{Masa Depan Jenis Tumbuhan Prioritas}

Berdasarkan studi yang dilakukan dapat digambarkan bahwa plasma nutfah terisi oleh banyak jenis yang memiliki multimanfaat dari kayu hingga non kayu maupun sebagai bank genetik jenis-jenis prioritas atau andalan setempat. Dengan demikian maka perlindungan kawasan plasma nutfah mutlak diperlukan dengan pengelolaan yang lebih optimal.

Jenis dengan kualitas kayu terbaik ditemukan antara lain kelompok meranti (Shorea spp), kempas (Koompasia malaccensis) dan ulin (Eusideroxylon melagangi Sym). Jenis penghasil buah-buahan antara lain jambu (Eugenia spp), mangga (Mangifera spp), langsat (Lansium spp), durian burung (Durio griffihtii) dan rambutan (Nephelium spp). Jenis tanaman obat antara lain pasak bumi (Euryacoma longifolia Jack) dan durian burung (Durio griffihtii).

\section{KESIMPULAN}

1. Studi floristik menunjukkan bahwa lokasi plasma nutfah yang menjadi objek pengamatan memiliki tingkat dominasi jenis-jenis penghasil tengkawang yang tergolong miskin jenis atau kurang melimpah sebagaimana ditunjukkan oleh nilai NP (nilai penting) Shorea pinanga $(9,43)$, Shorea macrophylla $(4,11)$ dan Shorea macistopterix $(0,63)$.

2. Keragaman penghasil tengkawang ditemukan tiga jenis yaitu Shorea macistopterix, Shorea macrophylla dan Shorea pinanga, sedangkan jenis Shorea stenoptera (tengkawang tungkul) yang menjadi jenis target tidak ditemukan. Tengkawang tungkul menghendaki habitat di sekitar aliran sungai sedangkan lokasi penelitian berupa kawasan perbukitan dataran tinggi.

3. Areal plasma nutfah di petak 35 dan 36 PT. Suka Jaya Makmur tidak representatif untuk ditetapkan sebagai plot konservasi eksitu jenis penghasil tengkawang karena miskin jenis target.

\section{DAFTAR PUSTAKA}

Anderson, J.A.R. 1975. The potential of illipe nuts (Shorea spp.) as an agricultural crop. In: Wiliams (ed.). Proceedings of Symposium on Southeast Asian Plant Genetic Resources, Bogor-Indonesia. 20-22 March, 1975. Bogor: BIOTROP.

Bawa, K.S. 1998. Conservation of genetic Resources in the Dipterocarpaceae. Biogeography and evolutionary Systematics of Dipterocarpaceae. In: Apannah, S. and J.M. Turnbull (eds.).A Riview of 
Dipterocarps: Taxonomy, Ecology and Sylviculture. Bogor: CIFOR.

Finkeldey, R. 2005. Introduction to Tropical Forest Genetics. Institute of Forest Genetiks and Forest Tree Breeding. University of Gottingen

Heriyanto, N.M. dan Subiandono, E. 2003. Status Kelangkaan Jenis Pohon di Kelompok Hutan Sungai Lekawai-Sungai Jengonoi, Sintang, Kalimantan Barat. Puslitbang Hutan dan Konservasi Alam, Bogor. Buletin Plasma Nutfah Vol.9 No.2 Th.2003.

Krishnapilly, B dan Tompsett, P.B. 1998. Seed Handling. Bio-geography and evolutionary systematics of Dipterocarpaceae. In: Apannah, S. and J.M. Turnbull (eds.). A Riview of Dipterocarps: Taxonomy, Ecology and Sylviculture. Bogor:CIFOR.

Odum, E.P. 1971. Fundamentals of Ecology (third edition). WB. Saunders Co. Philadelphia - London - Toronto.

Onrizal, Kusmana, C, Saharjo, B.H, Handayani, I.P dan Kato, T. 2005. Analisis Vegetasi Hutan Hujan Tropika Dataran Rendah Sekunder Di Taman Nasional Danau Sentarum, Kalimantan Barat. Jurnal Biologi, Vol.4, No.6, Desember 2005.

Purwaningsih. 2004. Sebaran Ekologi Jenis-Jenis Dipterocarpaceae Di Indonesia. Biodiversitas. Volume 5 (2) -Juli 2004. Hal: 89-95.

PT. SJM, 1992. Laporan Utama Dokumen Amdal PT. Suka Jaya Makmur. Kalimantan Barat. Soerianegara, I dan Indrawan, A. 1978. Ekologi Hutan Indonesia. Departemen Manajemen Hutan. Fahutan Institut Pertanian Bogor.
Sofia, D dan Riswan. 2008. Komposisi Jenis Semai Dan Pancang Di Hutan Alam Tropika Sebelum Dan Sesudah Pemanenan Kayu. Jurnal Penelitian Rekayasa. Volume 1, Nomor 1 Juni 2008.

Sumadiwangsa, S. 2001. Nilai dan Daya Guna Penanaman Pohon Tengkawang (Shorea spp) di Kalimantan. Buletin Pusat Litbang Teknologi Hutan Vol 2 (1). 2001.

Sutisna, U. 1981. Komposisi jenis Pohon Hutan Bekas Tebangan di Batulicin, Kalimantan Selatan. Deskripsi dan Analisa. Laporan No. 282. Puslit Hutan Bogor.

Tantra, I.G.M. 1979. The establishment of tengkawang plantations in Indonesia. In: Proceedings of the Symposium on Management of Forest Production in Southeast Asia, April, 19- 22, 1977. Bangkok-Thailand, Biotrop Special Publication No.4. Bogor: BIOTROP.

Thomson, A.J. 1993. Utilization of Superior Sources of Tree Germplasm In Timber Plantation Project. Mandala Agricultural Development Corporation (Madecor) in association with pacific Australia Reforestation Company. Pp 4-11. 
Lampiran 1. Daftar 10 Jenis dengan Nilai Penting terbesar Tingkat Pohon, Tiang, Pancang dan Semai Di Kawasan Plasma Nutfah PT Suka Jaya Makmur, Propinsi Kalimantan Barat

Tabel 1a. Daftar 10 Jenis dengan Nilai Penting terbesar Tingkat Pohon

\begin{tabular}{|c|l|c|c|c|c|c|}
\hline No & Jenis(Nama Lokal/IImiah) & KR & FR & DR & INP & Peringkat \\
\hline 1 & Shorea leprosula & 11,96 & 9,28 & 9,767 & 31,01 & 1 \\
2 & Eugenia cymosa & 9,88 & 9,15 & 7,290 & 26,32 & 2 \\
3 & Litsea firma (Blume) & 6,69 & 6,50 & 4,919 & 18,11 & 3 \\
4 & Shorea laevis & 2,09 & 2,39 & 11,544 & 16,02 & 4 \\
5 & Shorea macroptera & 4,72 & 4,77 & 4,798 & 14,29 & 5 \\
6 & Dryobalanop oblifolia & 3,62 & 3,45 & 4,197 & 11,27 & 6 \\
7 & Shorea pinanga & 3,07 & 2,92 & 3,435 & 9,43 & 7 \\
8 & Shorea palembanicca & 1,98 & 2,25 & 4,106 & 8,34 & 8 \\
9 & Dacryodes spp & 2,85 & 3,18 & 1,592 & 7,63 & 9 \\
10 & Polyalthia rumphii & 2,63 & 3,05 & 1,162 & 6,85 & 10 \\
\hline
\end{tabular}

Tabel 1b. Daftar 10 Jenis dengan Nilai Penting Terbesar Tingkat Tiang

\begin{tabular}{|c|l|c|c|c|c|}
\hline No. & \multicolumn{1}{|c|}{ Jenis (Nama Lokal/Ilmiah) } & KR & FR & INP & Peringkat \\
\hline 1 & Eugenia cymosa & 11.79 & 10.20 & 21.99 & 1 \\
2 & Myristica spp. Gronov & 10.00 & 8.93 & 18.93 & 2 \\
3 & Shorea leprosula & 9.10 & 7.83 & 16.94 & 3 \\
4 & Litsea firma (Blume) & 8.21 & 7.83 & 16.04 & 4 \\
5 & Palaquium obovatum & 6.42 & 5.83 & 12.25 & 5 \\
6 & Polyalthia rumphii & 4.33 & 5.10 & 9.43 & 6 \\
7 & Shorea gibbosa & 4.18 & 3.83 & 8.00 & 7 \\
8 & Polyalthia hypoleuca & 3.73 & 4.01 & 7.74 & 8 \\
9 & Dacryodes spp & 3.28 & 3.64 & 6.93 & 9 \\
10 & Shorea pinanga & 2,99 & 3,10 & 6,08 & \\
\hline
\end{tabular}

Tabel 1c. Daftar 10 Jenis dengan Nilai Penting terbesar Tingkat Pancang

\begin{tabular}{|c|l|c|c|c|c|}
\hline No & \multicolumn{1}{|c|}{ Jenis(Nama Lokal/Ilmiah) } & KR & FR & INP & Peringkat \\
\hline 1 & Shorea leprosula & 14.41 & 6.57 & 20.99 & 1 \\
2 & Shorea laevis & 14.72 & 5.06 & 19.78 & 19.27 \\
3 & Knema mandarahan & 8.91 & 10.37 & 16.57 & 3 \\
4 & Eugenia cymosa & 7.72 & 8.85 & 15.88 & 5 \\
5 & Litsea firma (Blume) & 7.67 & 8.22 & 13.36 & 6 \\
6 & Palaquium obovatum & 5.78 & 7.59 & 9.36 & 7 \\
7 & Shorea gibbosa & 4.43 & 4.93 & 7.05 & \\
8 & Glutta wallichii & 2.75 & 4.30 & 6.52 & \\
9 & Shorea Pinanga & 3.62 & 2.91 & 5.72 & \\
10 & Polyalthia hypoleuca & 2.43 & 3.29 & & \\
\hline
\end{tabular}

Tabel 1d. Daftar 10 Jenis dengan Nilai Penting terbesar Tingkat Semai

\begin{tabular}{|c|l|c|c|c|c|}
\hline No & Jenis (Nama Lokal/IImiah) & KR & FR & INP & Rangking \\
\hline 1 & Shorea laevis & 22.45 & 8.80 & 31.24 & 1 \\
2 & Litsea firma (Blume) & 5.38 & 8.49 & 13.87 & 2 \\
3 & Myristica spp. Gronov & 5.03 & 7.87 & 12.90 & 3 \\
4 & Shorea leprosula & 6.02 & 6.33 & 12.34 & 4 \\
5 & Shorea gibbosa & 7.06 & 4.94 & 12.00 & 5 \\
6 & Eugenia cymosa & 4.40 & 6.94 & 11.34 & 6 \\
7 & Palaquium obovatum & 4.22 & 5.40 & 9.62 & 7 \\
8 & Shorea pinanga & 3.93 & 3.86 & 7.79 & 8.69 \\
9 & Dacryodes spp & 3.30 & 3.39 & 3.70 & 9 \\
10 & Glutta wallichii & 1.97 & 3.70 & & 10 \\
\end{tabular}


Lampiran 2.Daftar pengelompokan jenis pada empat kriteria (sangat berperan, cukup berperan, kurang berperan dan langka) berdasarkan nilai penting tingkat pohon Di Kawasan Plasma Nutfah PT Suka Jaya Makmur, Propinsi Kalimantan Barat

\begin{tabular}{|c|c|c|c|c|c|}
\hline No & Jenis Pohon & INP & No & Jenis Pohon & INP \\
\hline $\mathrm{I}$ & Kriteria sangat berperan & & 5 & Dyera costulata & 1,48 \\
\hline 1 & Shorea leprosula & 31,01 & 6 & Durio griffihti & 1,32 \\
\hline 2 & Eugenia cymosa & 26,32 & 7 & Vatica rassak & 1,25 \\
\hline 3 & Litsea firma (Blume) & 18,11 & 8 & Glutta wallichii & 1,10 \\
\hline \multirow[t]{2}{*}{4} & Shorea laevis & 16,02 & 9 & Shorea parvifolia & 1,01 \\
\hline & & & 10 & Alstonya scholaris & 0,95 \\
\hline II & Cukup berperan & & 11 & Eusideroxylon melagangi & 0,94 \\
\hline 1 & Shorea macroptera & 14,29 & 12 & Shorea mecistopterix & 0,93 \\
\hline 2 & Dryobalanop oblifolia & 11,27 & 13 & Syzygium tawaense & 0,72 \\
\hline 3 & Shorea pinanga & 9,43 & 14 & Shorea gibbosa & 0,63 \\
\hline 4 & Coccoceras sp. & 8,34 & 15 & Ficus sp. & 0,58 \\
\hline \multirow[t]{2}{*}{5} & Dacryodes sp. & 7,63 & 16 & Dipterocarpus sublamellata & 0,52 \\
\hline & & & 17 & Beccaurea sp & 0,52 \\
\hline III & Kriteria Kurang berperan & & 18 & Santiria apiculata & 0,48 \\
\hline 1 & Polyalthia rumphii Merr & 6,85 & 19 & Memeycylon glomeratum & 0,48 \\
\hline 2 & Palaquium obovatum & 6,74 & 20 & Kibessia azurea DC & 0,47 \\
\hline 3 & Nephelium mutabile L & 6,68 & 21 & Horsfieldia sylvestris & 0,45 \\
\hline 4 & Knema mandarahan & 5,03 & 22 & Calophylum pulcherimum & 0,45 \\
\hline 5 & Shorea johorensis & 4,64 & 23 & Shorea atrinervosa & 0,39 \\
\hline 6 & Cratoxylum arborescen & 4,47 & 23 & Shorea bracteolata & 0,37 \\
\hline 7 & Syzygium leucoxylon & 4,31 & 24 & Garcinia celebica & 0,36 \\
\hline 8 & Hopea mengarawan & 4,19 & 25 & Kompassia malaccensis & 0,34 \\
\hline 9 & Shorea macrophylla & 4,11 & 27 & Sindora laecocarpa & 0,33 \\
\hline 10 & Eugenis cuprea & 4,03 & 28 & Palaquium gutta Baill & 0,33 \\
\hline 11 & Spondias sp & 3,34 & 29 & Eurycorma longifolia & 0,31 \\
\hline 12 & Tetramerista glabra & 3,04 & 30 & Shorea ovalis & 0,31 \\
\hline 13 & Artocarpus anysophylus & 3,02 & 31 & Ostodes paniculata & 0,30 \\
\hline 14 & Magnolia macklottii & 2,79 & 32 & Parkia javanica & 0,30 \\
\hline 15 & Exrospermum $\mathrm{sp}$ & 2,78 & 33 & Ganua motleyana & 0,29 \\
\hline 16 & Pometia alnifolia & 2,59 & 34 & Artocarpus elasticus & 0,29 \\
\hline 17 & Litsea polyantha & 2,58 & 35 & Anisophyllea ferruginea & 0,28 \\
\hline \multirow[t]{2}{*}{18} & Callophyllum soullatri & 2,36 & 36 & Nephelium caspidatum & 0,25 \\
\hline & & & 37 & Psichotria celebica Miq & 0,21 \\
\hline IV & Kriteria Langka & & & & \\
\hline 1 & Polyanthia lateriflora & 2,21 & & & \\
\hline 2 & Aghatis borneensis & 1,70 & & & \\
\hline 3 & Dipterocarpus crinitus & 1,64 & & & \\
\hline 4 & Dillenia exellsa & 1,57 & & & \\
\hline
\end{tabular}




\section{UCAPAN TERIMA KASIH}

Dewan Redaksi Jurnal Pemuliaan Tanaman Hutan menyampaikan rasa terimakasih dan penghargaan kepada Prof. Dr. Mohammad Na'iem selaku Mitra Bestari (Peer Reviewer) atas telaah dan saran terhadap isi naskah yang dimuat pada Jurnal Pemuliaan Tanaman Hutan Vol. 5 No. 2 Tahun 2011. 

